\title{
Cow's milk provocation induces an immune response to unrelated dietary antigens
}

\author{
H Suomalainen, E Isolauri, M Kaila, E Virtanen, H Arvilommi
}

\begin{abstract}
The activation of immune mechanisms was evaluated by the solid phase enzyme linked immunoassay of immunoglobulin and specific antibody secreting cells in 27 patients (aged from nine to 69 months), subjected to a diagnostic cow's milk challenge or a rechallenge. A significant rise in the total number of immunoglobulin secreting cells was associated with clinically positive $(n=17)$, but not a negative $(n=10)$ cow's milk challenge in all immunoglobulin isotypes. The number of specific antibody secreting cells against beta lactoglobulin, mean (95\% confidence interval), increased from $4 \cdot 8(1.4,15 \cdot 8)$ to $16.9(5 \cdot 5,52 \cdot 7)$ specific antibody secreting cells $/ 10^{6}$ cells, $\mathrm{p}=0.02$, and against casein from $2 \cdot 2(0 \cdot 8,6 \cdot 1)$ to $7 \cdot 5(2 \cdot 5,22 \cdot 5)$ specific antibody secreting cells $/ 10^{6}$ cells, $\mathrm{p}=\mathbf{0} \cdot 01$, in patients positive to challenge in the IgM class only, indicating defective immune elimination of milk antigens. In addition to the specific immune response to cow's milk antigens, an increase in IgM specific antibody secreting cells against an unrelated dietary antigen, gliadin, from $8 \cdot 2$ $(2 \cdot 1,31 \cdot 1)$ to $31 \cdot 0(14 \cdot 2,67 \cdot 6)$ specific antibody secreting cells $/ 10^{6}$ cells, $p=0 \cdot 01$, was observed. These results indicate that cow's milk challenge, in patients who have cow's milk allergy, induces a strong non-antigen specific immune response that includes a response against unrelated antigens concomitantly present in the intestinal lumen. Activation of such immune mechanisms may hence reflect increased antigenic load caused by the immune mediated lesion in the gut mucosa.

(Gut 1992; 33: 1179-1183)
\end{abstract}

Cow's milk allergy has hitherto been considered a temporary condition that improves or disappears with age. Evidence is now accumulating to suggest that this is only partially true, because there is considerable association with other allergic symptoms. ${ }^{1-3}$ These could manifest themselves either during active cow's milk allergy or later, when clinical tolerance to cow's milk has been acquired. The factors which determine the clinical outcome of cow's milk allergy are not fully understood.

We have previously shown that in cow's milk allergy the immune elimination of cow's milk antigens is deficient. ${ }^{+}$Exposure of the small intestine to cow's milk antigens causes a lesion to the gut mucosa and increases its permeability, permitting the entry of antigens through the impaired host barrier. ${ }^{56}$ Sensitisation to unrelated dietary antigens may thus ensue, giving rise to concurrent allergies to other foods.
To date, it is necessary to use clinical criteria for the diagnosis of cow's milk allergy. Cow's milk is eliminated from the diet for a period of time, after which a challenge test is carried out. The disappearance of symptoms during elimination and reappearance on challenge confirm the diagnosis.

The present study was undertaken to evaluate the immune response evoked by such a diagnostic cow's milk challenge. In addition to the immune response to beta lactoglobulin and casein, the fate of an unrelated dietary antigen, gliadin, was studied. For this purpose the ELISPOT assay was used.

\section{Methods}

\section{PATIENTS}

Altogether 32 children were studied. Of these, 22 had challenge proven cow's milk allergy manifested with either skin (urticaria (four), eczema (10) or gastrointestinal (loose stools) (six), diarrhoea (three), vomiting (two), abdominal pain (three)) symptoms. They were rechallenged to study whether or not clinical tolerance had been acquired. Five patients had experienced symptoms suggestive of cow's milk allergy (urticaria (one), loose stools (one), vomiting (two), diarrhoea (one)) and were admitted for diagnostic milk challenge after four weeks' milk elimination. During the elimination period the patients consumed a tolerated formula (soy or protein hydrolysate) or were given calcium supplementation. Five patients were on a diet devoid of gliadin and they were hence eliminated from the analysis. Four of them had had adverse reactions and in one patient cereals had not yet been introduced to the diet.

The study population thus consisted of 27 patients aged from nine to 69 months. Fourteen of these patients had dietary restrictions for egg (three), citrus fruits, peanuts, and fish (11) because of adverse reactions.

\section{MILK CHALLENGE PROTOCOL}

The challenge was started with a drop of cow's milk on the lips, whereafter milk was given in rising doses at two hour intervals. On day 1 , $2,5,10,20,50$, and $100 \mathrm{ml}$ of milk were given and on day 2 the normal milk intake appropriate for age was started. The challenge was stopped and the patients were examined, when any adverse reaction was noted. The reaction onset time was defined as the duration from the last given dose eliciting the symptoms. The patients were followed up over the one week period of the challenge and, for longterm tolerance; they were seen one month later. 
TABLE I Clinical reactions and their onset in response to diagnostic milk provocation

\begin{tabular}{llcc}
\hline & $\begin{array}{l}\text { Skin symptoms } \\
(n=7)\end{array}$ & $\begin{array}{l}\text { Gastrointestinal symptoms } \\
(n=10)\end{array}$ & $\begin{array}{l}\text { Statistical } \\
\text { value }\end{array}$ \\
\hline Reaction onset time $^{\star}(\mathrm{h})$ & $0 \cdot 74(0 \cdot 14,3 \cdot 80)$ & $6 \cdot 0(1 \cdot 13,26 \cdot 3)$ & $\begin{array}{l}\mathrm{t}=2 \cdot 33 \dagger \\
\mathrm{p}=0 \cdot 04\end{array}$ \\
Dose eliciting† symptoms $(\mathrm{ml})$ & $5 \cdot 0(1-200)$ & $200 \cdot 0(100-200)$ & $\begin{array}{l}\mathrm{z}=2 \cdot 09 \ddagger \\
\mathrm{p}=0 \cdot 03\end{array}$ \\
\hline
\end{tabular}

* Geometric mean (95\% confidence interval); Median (range); † Student's $t$ test; $\ddagger$ Mann-Whitney U test.

TABLE II Clinical history and laboratory features in patients positive and negative to clinical challenge

\begin{tabular}{|c|c|c|c|c|}
\hline & $\begin{array}{l}\text { Skin symptoms } \\
(n=7)\end{array}$ & $\begin{array}{l}\text { Gastrointestinal } \\
\text { symptoms } \\
(n=10)\end{array}$ & $\begin{array}{l}\text { Negative } \\
\text { challenge } \\
(n=10)\end{array}$ & $\begin{array}{l}\text { Statistical } \\
\text { value }\end{array}$ \\
\hline $\begin{array}{l}\text { Duration }{ }^{\star} \text { of breast feeding } \\
\text { (months) }\end{array}$ & $7 \cdot 6(2 \cdot 8)$ & $4 \cdot 1(3 \cdot 1)$ & $4 \cdot 6(3 \cdot 2)$ & \multirow{5}{*}{$\begin{array}{l}\mathrm{F}=2.11 \\
\mathrm{p}=0.15 \\
\chi^{2}=5.64 \\
\mathrm{p}=0.06 \\
\mathrm{~F}=0.36 \\
\mathrm{p}=0.70 \\
\mathrm{~F}=5.79 \\
\mathrm{p}=0.01 \\
\chi^{2}=6.20 \\
\mathrm{p}=0.04\end{array}$} \\
\hline $\begin{array}{l}\text { Positive family history of } \\
\text { allergy }\end{array}$ & $71 \%$ & $33 \%$ & $88 \%$ & \\
\hline $\begin{array}{l}\text { Age at the onset } f \text { of symptoms } \\
\text { suggestive to } C M\end{array}$ & $6 \cdot 0(4 \cdot 5,7 \cdot 9)$ & $4 \cdot 3(2 \cdot 2,8 \cdot 5)$ & $5 \cdot 2(2 \cdot 9,9 \cdot 5)$ & \\
\hline $\operatorname{IgE}(\mathrm{kU} / \mathrm{l}) \dagger$ & \multirow{2}{*}{$\begin{array}{c}138 \cdot 4(27 \cdot 6 \\
700 \cdot 6) \\
86 \%\end{array}$} & $5 \cdot 5(1 \cdot 3,23 \cdot 6)$ & $43 \cdot 8(8 \cdot 6,221 \cdot 2)$ & \\
\hline $\begin{array}{l}\text { Positive cow's milk-specific } \\
\text { RAST }(>0.4 \mathrm{kU} / \mathrm{l})\end{array}$ & & $17 \%$ & $50 \%$ & \\
\hline
\end{tabular}

${ }^{\star}$ Mean (SD); †Geometric mean ( $95 \%$ confidence interval).

C.MA = cow's milk allergy.
$\operatorname{Ig} A, \operatorname{IgG}$, and $\operatorname{Ig} M$, and to determine the number of specific antibody secreting cells, beta lactoglobulin, casein, and gliadin were used as coating antigens. There was an immune response if $>0.5$ specific antibody secreting cells $/ 10^{6}$ cells.

\section{STATISTICAL ANALYSIS}

Because of skewed distributions in immunoglobulin secreting cells and specific antibody secreting cell counts, logarithmic transformations (ln) were used. Analysis of variance (ANOVA) and Student's two tailed $t$ test were applied for comparing differences between groups in continuous variables, and the MannWhitney $U$ test for comparing medians. The repeated observations were studied using paired $t$ test and ANOVA for repeated measures. The $\chi^{2}$ test was used to determine differences in proportions.

\section{Results}

\section{CLINICAL CHARACTERISTICS}

The milk challenge was positive in $17 / 27(63 \%)$ and negative in 10 patients. The challenge elicited cutaneous symptoms in seven of 17 (41\%) cases, consisting of urticaria (four) or eczema (three); gastrointestinal symptoms were found in $10 / 17(59 \%)$ cases, including diarrhoea (one), loose stools (four), vomiting (three), and/ or abdominal pain (three).

Patients manifesting cow's milk allergy with skin symptoms reacted to lower volumes of milk than those with gastrointestinal symptoms (Table I). In addition, they often reacted immediately, while gastrointestinal symptoms were commonly manifested later.

The mean (SD) ages of the patients positive, $20 \cdot 1(7 \cdot 9)$ months, and negative, 29.4 (16.1) specific IgE antibodies, and also the serum total IgE values were measured before starting the challenge.

\section{ELISPOT ASSAY}

The total number of immunoglobulin secreting cells and the number of specific antibody secreting cells against beta lactoglobulin, casein, and gliadin were measured by the ELISPOT (solid phase enzyme linked immunoassay) method, as described previously. ${ }^{+}$In brief, mononuclear cells containing mainly lymphocytes were obtained by Ficoll-Hypaque (Pharmacia, Sweden) centrifugation of the heparinised blood. Isolated cells were washed three times in Hank's buffered salt solution (Flow Laboratories, Irvine, Scotland), then suspended in culture medium and adjusted to a final concentration of $2 \times 10^{6}$ cells $/ \mathrm{ml}$. The cells were incubated in antigen coated, flat bottomed microtitre plates (Immunoplate RI, a/s Nunc, Roskilde, Denmark). The antibodies were visualised by application of enzyme labelled antisera followed by a substrate agarose overlay. The counting of coloured spots, each representing one cell, was done with a stereo microscope after various periods of storage at $4^{\circ} \mathrm{C}$.

For determination of immunoglobulin secreting cells the wells were coated with antihuman

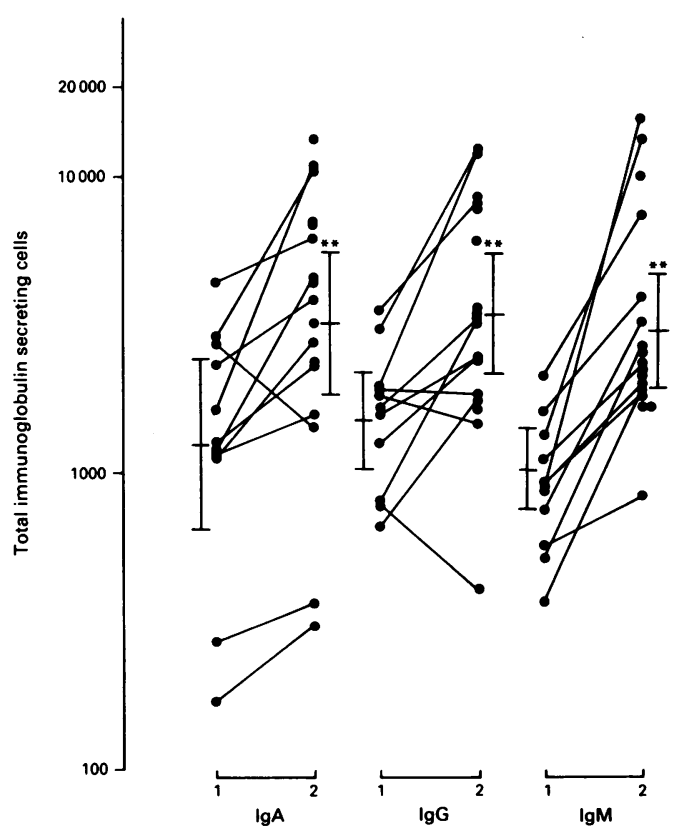

Figure 1: Total number of immunoglobulin secreting cells in patients positive to cow's milk challenge (log scale) before (1) and after (2) diagnostic challenge. Horizontal lines represent $\star \star p<0.01$ compared with the prechallenge values (paired $\mathrm{t}$ test). and after (2) diagnostic challenge. Horizontal lines represent 


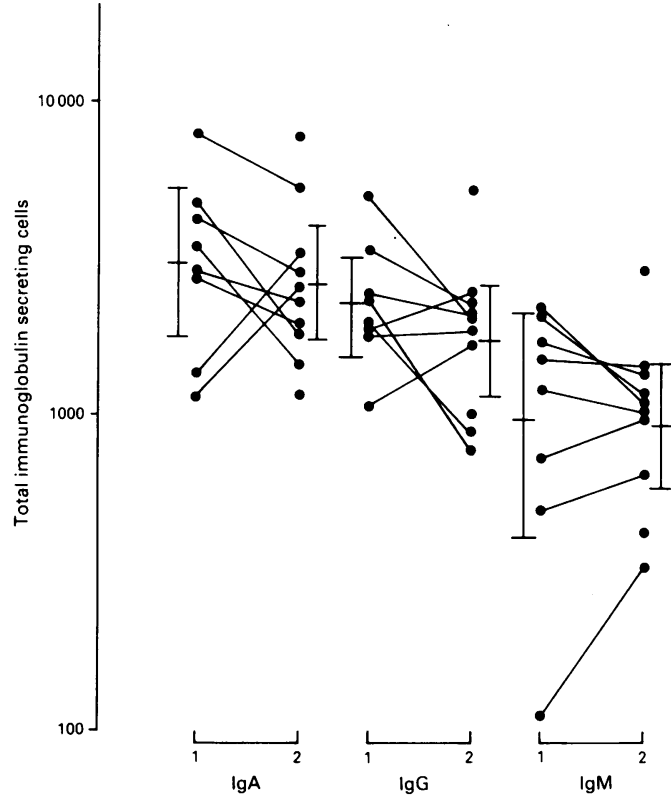

Figure 2: Total number of immunoglobulin secreting cells in patients with negative response to challenge (log scale) before (1) and after (2) the diagnostic challenge. Horizontal lines represent the geometric means with $95 \%$ confidence interval.

months, to oral challenge were comparable at the time of the provocation; the difference of 9.3 months with $95 \%$ confidence interval of $(-0 \cdot 2$, 18.8) was statistically not significant. The patients with skin symptoms had positive cow's milk-specific radioallergosorbent test values, which were less frequent in patients with gastrointestinal symptoms (Table II).

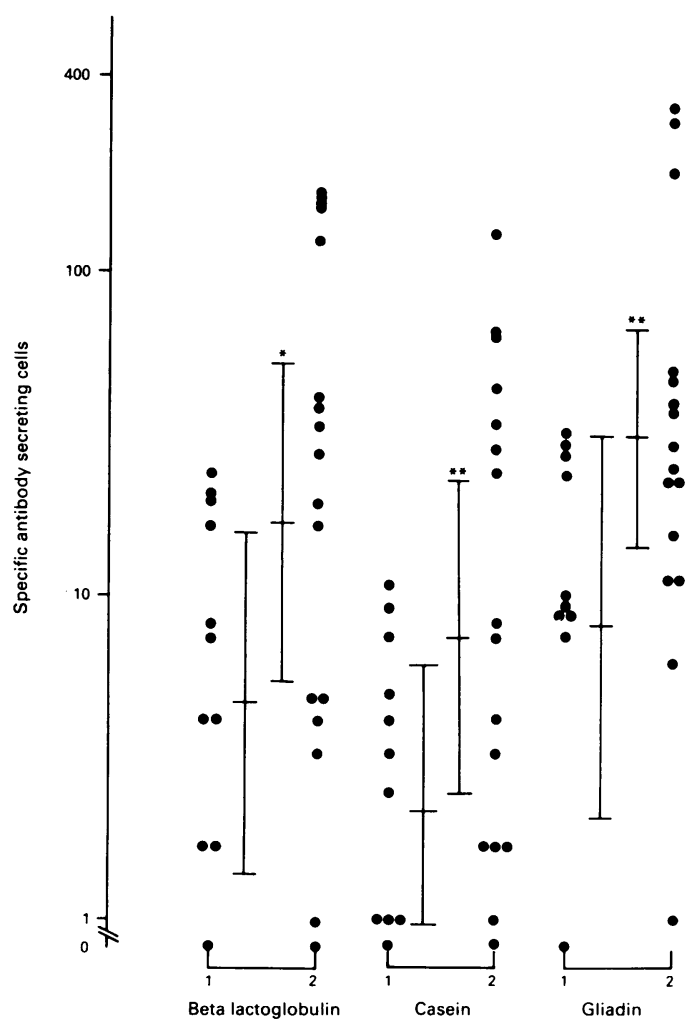

Figure 3: Number of specific antibody secreting cells against beta lactoglobulin, casein and gliadin in the IgM class before (1) and after (2) milk challenge in patients positive to clinical challenge. Horizontal lines represent the geometric means with $95 \%$ confidence interval. ${ }^{\star} p<0.05,{ }^{\star} p<<0.01$ compared with prechallenge values (paired $\mathrm{t}$ test)
NON-ANTIGEN SPECIFIC IMMUNE RESPONSE

(IMMUNOGLOBULIN SECRETING CELLS)

There was a statistically significant increase in the number of immunoglobulin secreting cells from day 1 to day 8 in patients with positive clinical reaction to challenge (Fig 1). By contrast, in patients negative to challenge the mean number of immunoglobulin secreting cells decreased during the challenge period (Fig 2).

ANTIGEN-SPECIFIC IMMUNE RESPONSE (SPECIFIC ANTIBODY SECRETING CELLS) TO BETA

LACTOGLOBULIN AND CASEIN

A distinct rise in the number of specific antibody secreting cells to beta lactoglobulin and casein was detected in patients reacting positively to challenge in the IgM class (Fig 3). Conversely, the specific antibody secreting cell responses from day 1 to day 8 in the $\operatorname{IgA}$ and $\operatorname{IgG}$ classes were minimal: the $\operatorname{IgA}$ secreting cells against beta lactoglobulin increased from $0.2(0 \cdot 1,0 \cdot 7)$ to $1 \cdot 2(0 \cdot 3,4 \cdot 8)$ specific antibody secreting cells/ $10^{6}$ cells, and the IgG secreting cells against beta lactoglobulin from $0 \cdot 1(0.04,0.4)$ to $0.3(0 \cdot 1$, $0.9)$ specific antibody secreting cells $/ 10^{\prime}$ cells; the antibody secreting cells in the IgA class against casein increased from $0 \cdot 1(0.04,0.4)$ to $0.6(0.2$, $2 \cdot 1)$ specific antibody secreting cells $/ 10^{6}$ cells, and in the IgG class from $0 \cdot 2(0 \cdot 1,0 \cdot 7)$ to $1 \cdot 1$ $(0 \cdot 4,3 \cdot 2)$ specific antibody secreting cells $/ 10^{n}$ cells. In patients negative to challenge there was no increase in the number of specific antibody secreting cells against beta lactoglobulin and casein; Figure 4 depicts the concentrations of IgM specific antibody secreting cells to beta lactoglobulin and casein in these patients.

According to the ANOVA for repeated measures the interaction term between groups and periods was statistically significant; for $\operatorname{IgM}$ specific antibody secreting cells to beta lactoglobulin, $p=0.007$, and to casein, $p=0.02$. This

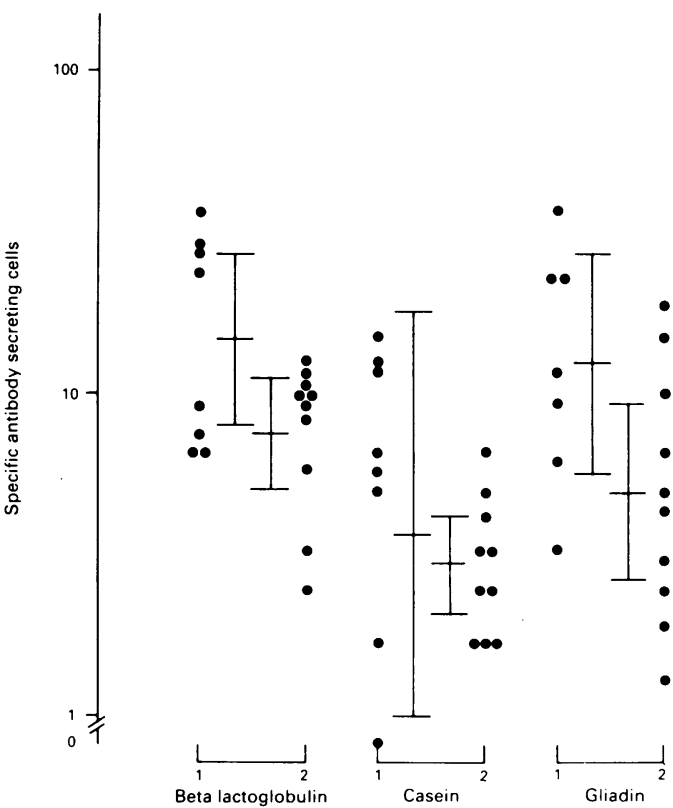

Figure 4: Number of specific antibody secreting cells against beta lactoglobulin, casein and gliadin in the IgM class before (1) and after (2) the milk challenge in patients negative to clinical challenge. Horizontal lines represent geometric means with $95 \%$ confidence interval. 
means that the group behaviour at successive specific antibody secreting cells measurement points was different: in patients with positive clinical response to the challenge the mean number of specific antibody secreting cells increases and in those negative to the clinical challenge it decreases.

ANTIGEN SPECIFIC IMMUNE RESPONSE (SPECIFIC ANTIBODY SECRETING CELLS) TO GLIADIN

The patients positive to cow's milk challenge also mounted a specific antibody secreting cells response against gliadin in the IgM class (Fig 3), which was not seen in patients negative to challenge (Fig 4). The ANOVA for repeated measures showed significant interaction $(p=$ 0.002 ) between groups and periods, indicating that the differences at successive measurements of IgM specific antibody secreting cells to gliadin between patients positive and negative to challenge were statistically significant.

\section{Discussion}

The results of the present investigation agree with those of previous studies indicating that immune mechanisms are activated in cow's milk allergy, ${ }^{+10}$ and further extend these findings to unrelated dietary antigens encountered by the enteral route.

We used a new immunoassay, the ELISPOT, to measure immune response during cow's milk challenge. The ELISPOT is a promising method for indirect study of the immunologic events in the gut. ${ }^{810}$ The method is based on the maturation cycle of gut associated lymphoid tissue derived lymphocytes. After contact with intraluminal antigens, the lymphocytes travel to mesenterial lymph nodes to mature and by way of peripheral blood back to the gut mucosa to secrete antibodies against the priming antigen. ${ }^{12}$ The cell migration cycle is based on experimental work in animal studies as well as in human studies of oral vaccination. ${ }^{8911-13}$ Evidence in support of the concept has been provided by adoptive transfer experiments in which B-lymphocytes from mucosa associated lymphoid tissues have been shown to repopulate the mucosa. ${ }^{1+15}$ The intensity of the immune response as measured by the ELISPOT correlates with the capability of the antigen of adhering to the epithelial cells. ${ }^{16}$

In the present study a sharp rise in immunoglobulin secreting cells was measured during a clinically positive milk challenge, reflecting nonantigen specific immune response. At the same time, the antigen specific immune response was small and inconsistent. This indicates that immune system elimination of cow's milk antigens is defective in cow's milk allergy. In a previous follow up study we found that patients who had challenge proven cow's milk allergy acquired clinical tolerance to cow's milk when the antigen specific immune response had developed. ${ }^{10}$

Studies in sensitised experimental animals have shown that exposure of the gut mucosa to dietary antigens leads to intestinal injury. ${ }^{17-20}$ The final result of the immune mediated tissue damage may include mucosal edema, commonly associated with type 1 hypersensitivity, or villus effacement and crypt hyperplasia associated with cell mediated reactions. ${ }^{19}$ In patients who have cow's milk allergy, a clinically positive milk challenge induces the increased permeability of gut mucosa, irrespective of whether the symptoms arise from the gut or the skin. ${ }^{6}$ This is in support of the notion that deranged intestinal barrier is not primary to the allergic state, but rather secondary to the hypersensitivity reaction.

Although the intestinal hypersensitivity reaction is highly specific to the priming antigen, the resulting enhancement of permeability is not necessarily antigen specific. On account of that, there is enhanced absorption of unrelated intraluminal antigens during a positive cow's milk challenge. The sharp rise in the number of specific antibody secreting cells against gliadin may hence reflect increased antigenic load caused by the immune-mediated lesion in the gut mucosa. Repetition of such hypersensitivity reaction could result in broadening of allergic symptomatology.

The clinical implication of this study is that appropriate dietary elimination is crucial in the treatment of patients who have cow's milk allergy. Furthermore, the question remains how frequently clinical challenges are needed to support the diagnosis and how often the challenges can be carried out without impairing the prognosis of the disease.

The authors thank The Emil Aaltonen Foundation (HS) and The Paulo Foundation (EI) for financial support.

1 Hill DJ, Firer MA, Ball G, Hosking CS. Recovery from milk allergy in early childhood: antibody studies. F Pediatr 1989 114: 761-6.

2 Eggleston PA. Prospective studies in the natural history of food allergy. Ann Allergy 1987; 59: 179-82.

3 Bishop JM, Hill DJ, Hosking CS. Natural history of cow milk allergy: clinical outcome. $\mathcal{F}$ Pediatr 1990; 116: 862-7.

4 Isolauri E, Virtanen E, Jalonen T, Arvilommi H. Local immune response measured in blood lymphocytes reflects the clinical reactivity of children with cow's milk allergy. Pediatr Res 1990; 28: 582-6.

5 Heyman M, Grasset E, Ducroc R, Desjeux JF. Antigen absorption by jejunal epithelium of children with cow's milk allergy. Pediatr Res 1988; 24: 197-202.

6 Jalonen $T$. Identical intestinal permeability changes in children with different clinical manifestations of cow's milk allergy. F Allergy Clin Immunol 1991; 88: 737-42.

7 Metcalfe DD, Sampson HA. Workshop on experimental methodology for clinical studies of adverse reactions to foods and food additives. 7 Allergy Clin Immunol 1990;86. $421-42$.

8 Kantele A, Arvilommi H, Jokinen I. Specific immunoglobulin-secreting human blood cells after peroral vaccination against salmonella typhi. F Infect Dis 1986; 153: $1126-31$

9 Forrest BD. Identification of an intestinal immune response by using peripheral blood lymphocytes. Lancet 1988; i: 81-3.

10 Isolauri E, Suomalainen H, Kaila M, Jalonen T, Soppi E Virtanen E, et al. Local immune response in cow's milk allergy - follow-up of patients retaining allergy or becoming tolerant. 7 Pediatr 1992; 120: 9-15.

11 Lycke N, Lindholm L, Holmgren J. Cholera antibody production in vitro by peripheral blood lymphocytes following oral immunization of humans and mice. Clin Exp Immunol 1985;62:39-47.

12 Doe WF. The intestinal immune system. Gut 1989; 30: $1679-85$.

13 Czerkinsky C, Svennerholm AM, Quiding M, Johnsson R Holmgren J. Antibody-producing cells in peripheral blood after oral cholera vaccination of humans. Infect Immun 1991 59: $996-1001$

14 McDermott MR, Bienenstock J. Evidence for a common mucosal immunologic system. I. Migration of B immunoblasts into intestinal, respiratory and genital tissues. F Immunol 1979; 122: 1892-8

15 Weisz-Carrington P, Roux ME, McWilliams M, PhillipsQuagliata JM, Lamm ME. Organ and isotype distribution of plasma cells producing specific antibody after oral immunization: evidence for a generalized secretory immune system. 7 Immunol 1979; 123: 1705-8. 
16 Van Der Heijden PJ, Bianchi ATS, Dol M, Pals JW, Stock W, Bokhout BA. Manipulation of intestinal immune responses against ovalbumin by cholera toxin and its B subunit in mice. against ovalbumin by choler

17 Curtis GH, Patrick MK, Catto-Smith AG, Gall DG. Intestinal anaphylaxis in the rat. Effect of chronic antigen exposure. Gastroenterology 1990; 98: 1558-66.

18 Heyman M, Andriantsoa M, Crain-Denoyelle AM, Desjeux JF. Effect of oral or parenteral sensitization to cow's milk on mucosal permeability in guinea pigs. Int Arch Allergy Appl Immunol 1990; 92: 242-6.

19 Mowat A. The cellular basis of gastrointestinal immunity. In Marsh $\mathrm{MN}$, ed. Immunopathology of the small intestine. Chichester: Wiley \& Sons, 1987: 41-71.

20 Turner MW, Barnett GE, Strobel S. Mucosal mast cell activation patterns in the rat following repeated feeding of antigen. Clin Exp Allergy 1990; 20: 421-7. 